\title{
A CLINICAL AND LABORATORY EVALUATION OF FOUR FLUOTHANE VAPORIZERS ${ }^{1}$
}

\section{IAIN M MacKay, M $\mathbf{D}^{2}$ and Werner KaIOW, M $\mathrm{D}^{3}$}

WIDESPREAd CONTINUING INTEREST in 2 brom, 2 chlor $1,1,1$, fluoroethane, known as halothane or more commonly Fluothane, has resulted over the past few months in many attempts to make its use safer and at the same time more economical. Certain apparatus has been designed to facilitate its use, particularly by the less experienced anaesthetist. This paper describes the clnical and laboratory investigation of four especially designed Fluothane Vapornzers. Each of these is intended to increase the margin of safety in the use of an extremely potent drug and to provide something in the nature of a "flowmeter" for its more convenient use.

Certam desirable characteristıcs of vaporizers for a drug of the potency of Fluothane may be stated here.

(a) Accuracy of standard settings or calıbrations.

(b) Minimal variation in delivered concentration due to changes in ambient temperature and pressure

(c) Minimal decrease in delivered concentration due to flow of gases through the vaporizer.

(d) Minimal variation in concentration due to movement or agitation of vaporizer.

(e) Minimal changes in concentration due to "flushing through" with oxygen

(f) Minimal change in concentration due to changes in fluid level

Many of these performance characteristics can only be determined by laboratory investigation which has for this group of vaporizers been carred out in the laboratories of the Department of Pharmacology at the University of Toronto

The vaporizers investigated in this trial are the Fluotec Vaporizer (Fig. 1), the FNS Fluothane Vaporizer (Fig 2), the Ohio-Heidbrink Fluothane Vaporizer (Fig. 3); and the B.O C. Boyle's Fluothane Bottle (Fig 4).

The first three are calibrated in percentage of Fluothane by volume The fourth has an extended scale of 10 equal divisions.

\section{Clinical}

The series includes a complete range of major and mmor surgical, obstetrical, and gynaecological cases, of which more than 600 have been done by the one investigator. This report includes only 478 of these cases, those for which one of the four vaporizers was employed. It excludes 50 cases of thoracic, abdominothoracic, and upper abdominal surgery for which.an automatıc ventilator was used, as in each of these cases the Fluotec Vaporizer was employed and no comparative figures with other vaporizers are available. It is noteworthy, how-

1Presented at the Annual Meetung of the Canadian Anaesthetısts' Society, June 24, 1958

2Department of Anaesthesia, University of Toronto and Toronto General Hospital

3Department of Pharmacology, University of Toronto 


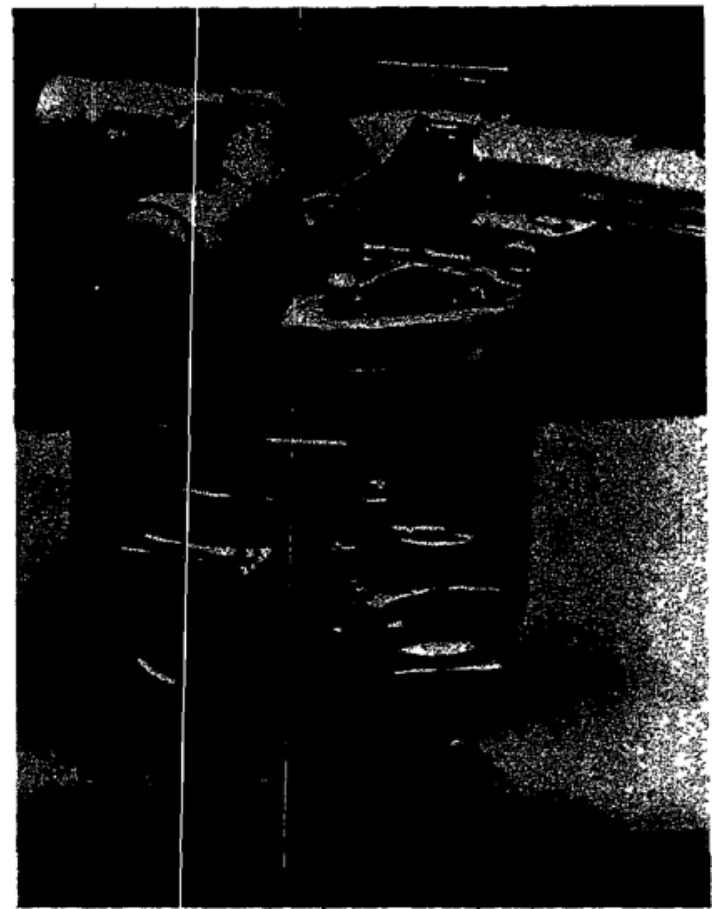

Figure 1

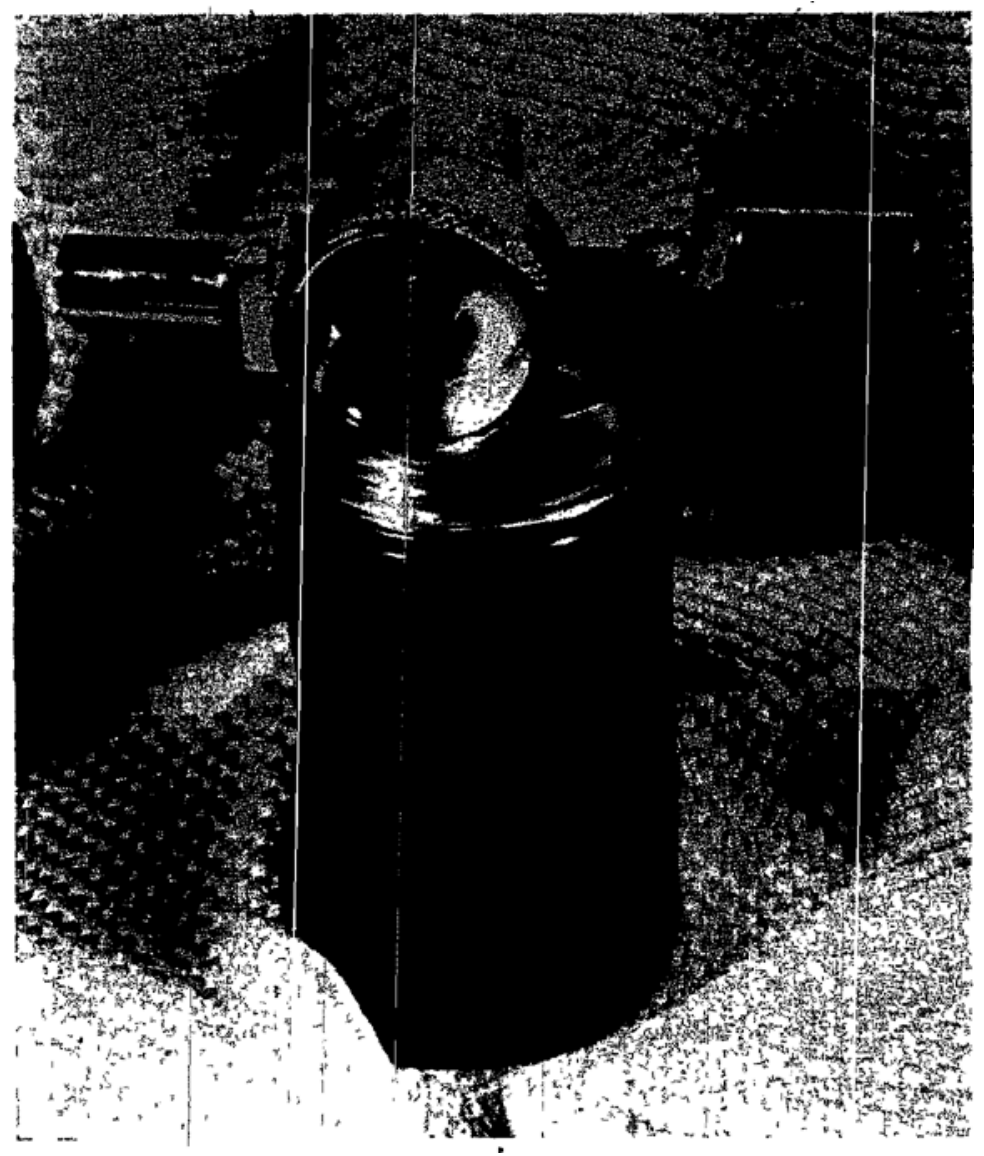

Figure 2 


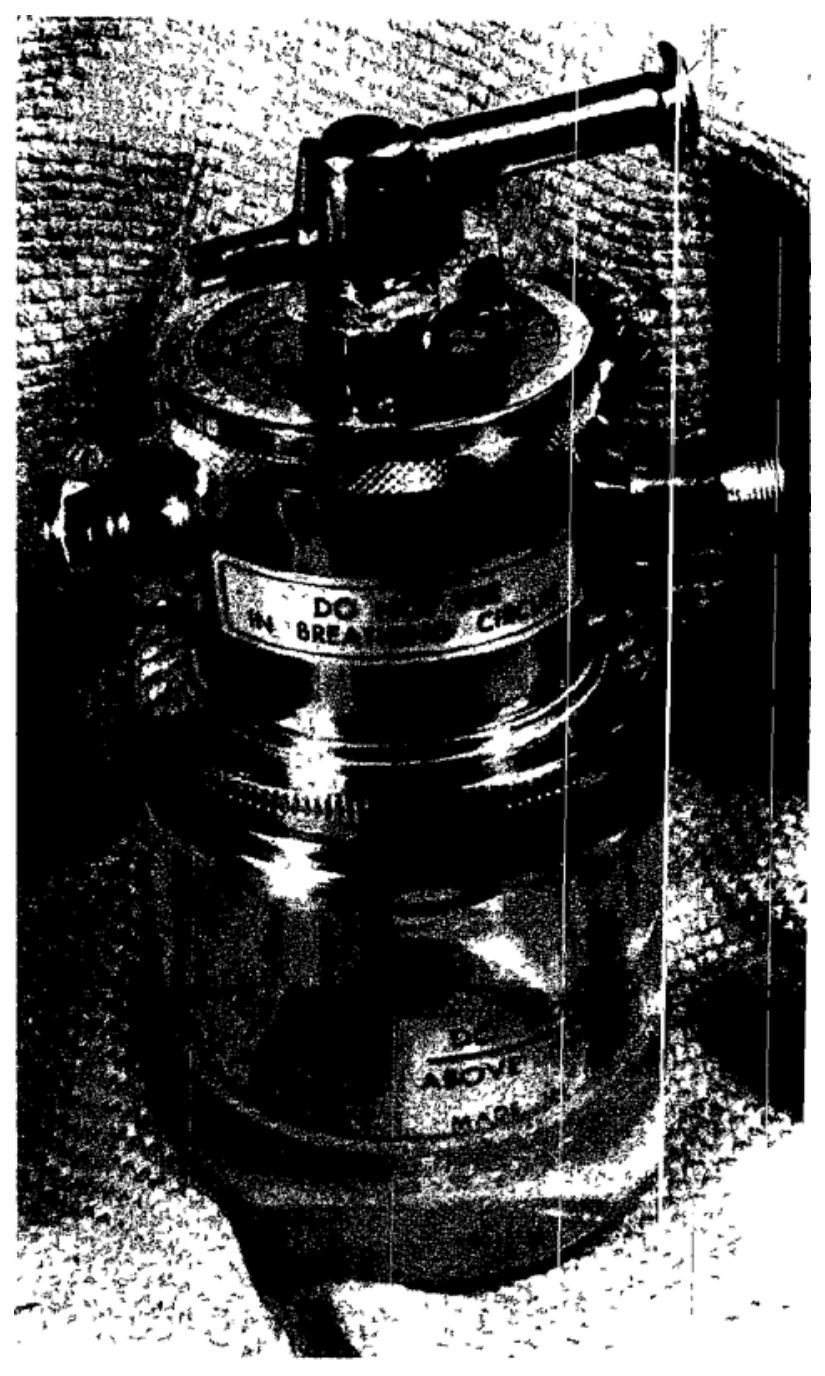

Figure 3

ever, that the Fluotec was used because the maintenance concentration of Fluothane with alternating positive and negative piessure ventilation is often so low that only this vaporizer could be rehed upon for even, prolonged maintenance

Each of the vaporizers has been used in the same manner clinically No attempt was made to select cases on the basis of surtability, 11sk or other chalacterıstic. No standard preoperative medication or method of anaesthesia was used. Curare was not used as a relaxant, but both Suxamethonium and Gallamine were employed when relaxation was necessary A yariety of gas machines was employed including the Herdbrink (several different models) and Boyle's machmes (BOC, MIE and Loos) A variety of gas crrcuits was used including semi-closed with carbon dioxide absoiption, contmuous flow, and non-rebreathing. Table I shows the frequency of use of each vaporizer Table II shows the frequency with which the different circuits were employed. 


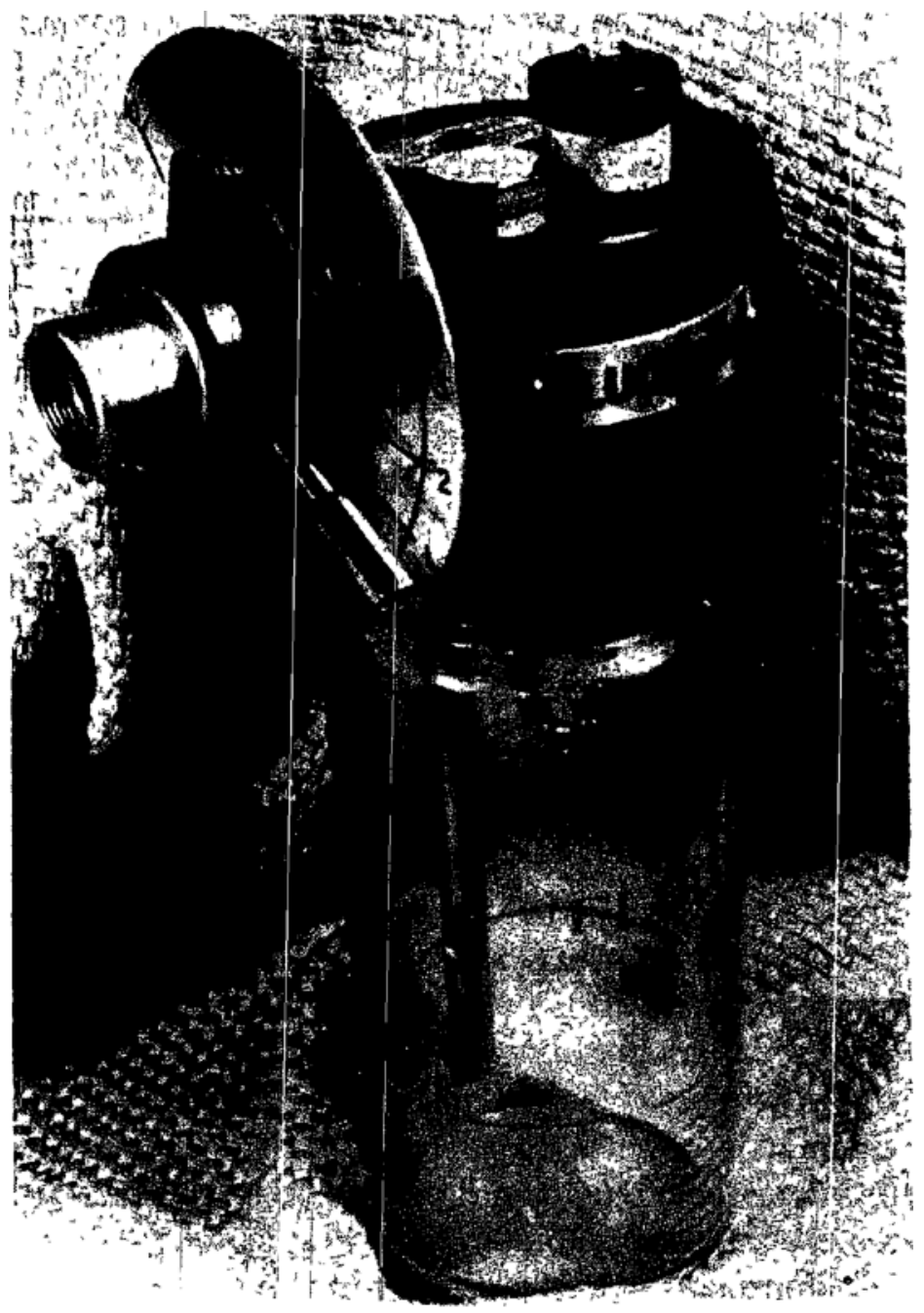

Figure 4

TABLE I

\begin{tabular}{lr}
\hline Vaporizer & Number of cases \\
\hline Fluotec (\% calıbrated) & 302 \\
Ohiq (\% calibrated) & 66 \\
FNS (\% calibiated) & 46 \\
B O C (not calibrated) & 64 \\
TotaL & 478 \\
\hline
\end{tabular}

TABLE II

\begin{tabular}{lc}
\hline Circuit & Number of cases \\
\hline Semi-closed (circle absorption) & 55 \\
Seml-closed (to-and-fro absorption) & 23 \\
Direct flow (no $\mathrm{CO}_{2}$ absorption) & 147 \\
Direct flow non-rebreathing & 253 \\
Tot 4L & 478 \\
\hline
\end{tabular}


In each case in this series an effort was made to use the minumal amount of Fluothane consistent with good anaesthetic technique and the requirements of each individual patient, and since this investgation was primarily for purposes of comparison, a record of all percentage or dial settings was kept for each case and for each vaporizer to show the dose necessary for induction and the dose necessary for maintenance of anaesthesia.

In most cases induction of anaesthesia was accomplished with a small dose of thopentone. However, a large number of cases were induced with Fluothane, nitrous oxide and oxygen.

\section{Observations}

Many of the phenomena observed in this series show the characteristics of Fluothane. These are now common knowledge, having been reported by many investigators and will be mentioned only in relation to the performance of the various vaporizers.

Each of the four vaporizers investıgated is clinically usable and useful. The most $\hat{t}$ accurate, and the one giving the smoothest maintenance at any safe level of anaesthesia, is the Fluotec. It appears to be unaffected by ambient temperature, by high rates of gas flow, or by changes in the flurd level, and need only be refilled at fairly long intervals, that is, when the flurd level falls below the glass window.

Each of the other vaporizers shows changes clinically with changes in fluid level and with the cooling due to the flow of gases over the surface of the Fluothane. A maintenance setting, adequate at first, after fifteen or twenty minutes often becomes inadequate, allowing the patient to react violently to stimulation or to waken. Readjustment of the setting or refilling of the vaporizer is then necessary. The Ohio vaporizer, probably due to the greater surface area exposed for vaporization and to its water jacket, maintans the desired level of delivery longer than either the FNS or the BOC Vaporizer.

Systolic blood pressure fall during both induction and inaintenance in anaesthesia is less frequent with the Fluotec than with the other vapornzers.

Using the Fluotec we found in a large sernes of cases that induction of anaesthesia could readily be performed for most patients with a concentration of 2.5 to 3 per cent Fluothane in 50 per cent nitrous oxide and oxygen. Following induction, maintenance of anaesthesia required a concentration of only 05 to 07 per cent if any necessary relaxation was obtained by the use of small doses of intravenous relaxant When the FNS Vaporizer became avalable, it was at once noted that for induction the dial settung of this vaporizer had to be in the range of 2.8 to 44 per cent Usually the higher settung was required For maintenance, settings of 08 to 1.6 per cent were required with the 12 per cent setting being most commonly used. It was obvious that the Fluotec and FNS Vaporizer were calibrated differently and this observation led to the decision to investigate the vaporizers by laboratory methods.

The Ohio Vaporizer gave somewhat different clinical data. Induction settings or initial Fluothane settings of 3 per cent were necessary and were often inade- 
quate, although slight agitation of the vaporizer appeared to deepen the anaesthesia. Maintenance settungs, however, were in the range from 0.5 to 1.0 per cent, usually the lower figure.

The BOC Vaporizer is not callbrated in percentage, but uses an extended scale with ten equal divisions. With $100 \mathrm{cc}$. of Fluothane in the BOC bottle, induction or initial setting was 4.0 to 45 and the maintenance setting was about 2 Using the vaporizer with only, $50 \mathrm{cc}$. of Fluothane in the bottle, as was more frequently done in this series, extended the operating range somewhat, allowing maintenance settings between 2 and 2.5 to be used whle the induction setting was often 5 or 6 .

\section{Laboratory Studies}

Following the clinical observation of considerable performance differences in the four vaporizers it was decided to investigate each of them in the laboratory and to compare them for accuracy, efficiency, reaction to agitation or moving of the gas machine, flushing through with oxygen, reaction to changes in pressure within the circuit, and fall off in delivered concentration due to the cooling effect of the gas flow and changes in fluid level.

A standard method of investigation was devised, clinscal in type, but consistent with laboratory accuracy The gas source for testing all vaporizers was a BOC Pedestal Model Boyle's machine with rotameters capable of delivering accurately measured gas flows from one to fifteen litres per munute.

The vaporizer to be investigated was adapted directly to the Boyle's machine and the gas and vapour mixture was led by thick-walled half-inch rubber tubing through a BOC spring-loaded exhalation valve to the cell of a Beckman direct recording spectrophotometer (model DK II) calibrated for Fluothane. The exhalation valve was left open and a water manometer was interposed between the valve and the tube leading to the cell. The pressure within the circuit with this valve open was observed to be from 0.5 to $1 \mathrm{~cm}$. of water. Adequate mixing of gas and vapour was assumed because of the various calibres of the several tubes and connectors used in the circuit and the consequent turbulence of gas flow.

Observations were made of true delivered percentage of Fluothane $(v / v)$ at each of the main dial settings of each vaporizer and at different gas flow rates. Reaction to change in pressure was observed by closing the exhalation valve, thereby increasing the pressure within the circuit to a maximum of $10 \mathrm{~cm}$. of water. Reaction to agitation of each vaporizer for a period of ten seconds was observed and recorded. The reaction to flushing the system with a high flow of oxygen was recorded for each vaporızer.

The concentration of Fluothane delivered by each vaporizer was measured in the following way.

\section{Method of Measuring Concentration of Fluothane}

All determinations were made in a Beckman Recording Spectrophotometer model DK II using ultraviolet light in wavelength $228 \mathrm{~m} \mu$ (1). The absorption cells had a light path of 50 milhmetres with a capacity of $15 \mathrm{cc}$. One of these 
cells was used for calibration and had only one opening, which could be closed with a ground glass stopper. The other cell which was used for contunuous recording of the concentration of Fluothane in a stream of gas had two openings, one at each end. The openings were wide enough so that a gas How through the cell of 15 litres per minute created a back pressure of less than 1 millimetre of mercury. Polyethylene tubes were attached to both openings to carry the inflowing and outflowing gas into the spectrophotometer while the cell was shelded from outside light. During all measurements a strong fan was used to blow cool air against the cell compartment so that the temperature in this compartment was nearly identical with the room temperature (between $22^{\circ}$ and $27^{\circ} \mathrm{C}$ ).

\section{Calibration}

The absorption cell was opened to room air and the cell plus glass stopper were weighed to the nearest tenth of a milligramme, hundredths of a mill:gramme being estimated. A small amount of liquid Fluothane was pipetted into the cell where it immediately vaporized; the cell was then closed, weighed and the absorbance at $228 \mathrm{~m}_{\mu} \mu$ was determined. Both weight and absorbance remained nearly constant for at leasty twenty minutes, indicating that the loss of vapour during these procedures was negligible. Thereafter the cell was opened for a few seconds so that some vapour escaped and the weighing and the spectrophotometric measurement were repeated. By such a stepwise diminution of the vapour, the relation between weight of cell contents and absorbance was obtaned. The same procedure was repeated several times in succession. Three different batches of Fluothane were used. Control determinations were made on two following days. The data thus obtained are shown in Figure 5.

The observed weight of cell contents is proportional, but not equal, to the weight of Fluothane; the observed weight equals the weight of Fluothane vapour minus the weight of displaced air. If one mol of Fluothane vapour (197.4 gm.) displaces one mol of air ( $29 \mathrm{gm}$ ), an observed weight of $168.4 \mathrm{gm}$. indicates the presence of one mol of Fluothane. Then the observed weight of the cell contents multiplied by $197.4 / 1684=1.175$ gives the werght of the Fluothane present in the cell.

According to the curve in Figure 5 the absorbance is 1.18 if the cell contents weigh $5 \mathrm{mg}$., that is if $1.175 \times 5=5875 \mathrm{mg}$. of Fluothane are contained in the $15 \mathrm{cc}$. volume of the cell. This concentration equals $392 \mathrm{mg}$. per litre as indicated on the upper scale of Figure 5.

Clinical usage demands that the concentration of Fluothane vapour be expressed as percentage $(\mathrm{v} / \mathrm{v})$. Thus 1 per cent Flusthane at $0^{\circ} \mathrm{C}$ and $760 \mathrm{~mm}$. $\mathrm{Hg}$ (STP) is a mixture of $10 \mathrm{cc}$. of vapour and $930 \mathrm{cc}$. of gas. If one mol of Fluothane weighs $197^{\prime} 4 \mathrm{gm}$ and occupies at STP 22.4 litres, the weight of $10 \mathrm{ml}$. of Fluothane vapour would be $882 \mathrm{mg}$., the weight of $990 \mathrm{ml}$. of air is $1280 \mathrm{mg}$. This Fluothane concentration of $882 \mathrm{mg}$. per litre would have an absorbance of 0266 at $228 \mathrm{~m} \mu$ in a light path of $50 \mathrm{~mm}$.

If this mixture of Fluothane and alr were subjeeted to a pressure of $750 \mathrm{~mm}$. $\mathrm{Hg}$ and a temperature of $25^{\circ} \mathrm{C}$ it would occupy a volume of 1.106 litres. Therefore, fewer molecules of Fluothane would be in the given light path in the 


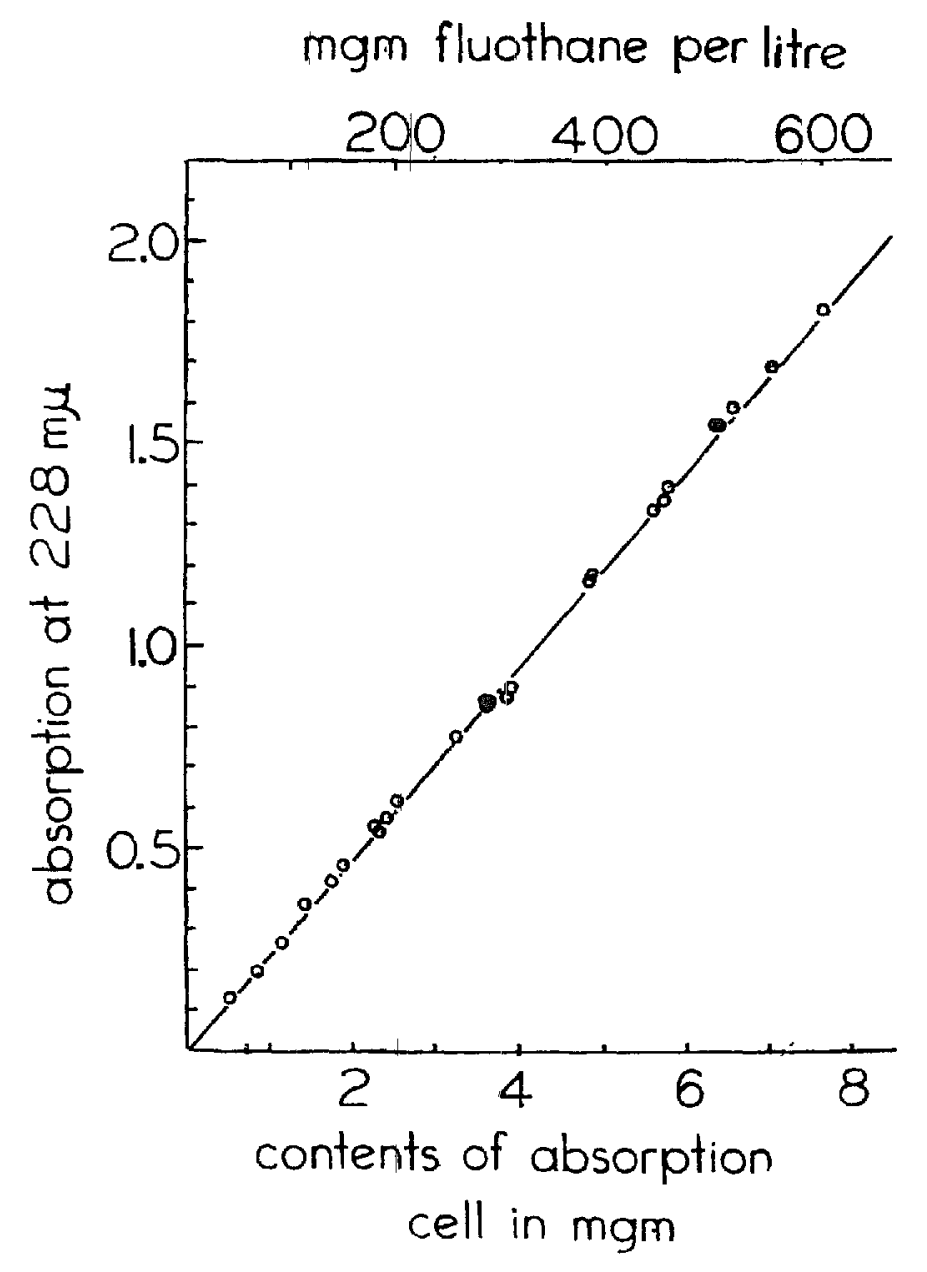

PIC.TRE 5

absorption cell so that the absorbance of 1 per cent Fluothane under these conditions would be only 0.241 . Hence, in order to express the spectrophotometrically measured concentrations of Fhothane in percentage, attention was always paid to the barometric pressure. In the course of the experiments described in this paper the absorbance of 1 per cent Fluothane ranged from 0.239 to 0.245 .

\section{Observations}

Figure 6 shows the spectrophotometric recording for the Fluotec Vaporizer at all main dial settings and at gas flow rates from 4 litres per minute to 14 litres per minute. It will be observed that at flows from $6 \mathrm{~L} . / \mathrm{min}$. to $14 \mathrm{~L} . / \mathrm{min}$. the indicated percentage was within 20 per cent of the true percentage delivered as indicated on the right ordinate of the figure. At a flow of $4 \mathrm{~L} . / \mathrm{min}$. the concentration delivered at dial settings of 0.5 and 1.0 per cent is somewhat lower than the calibration, but repeated tests have shown this variation to be predictable and constant. 


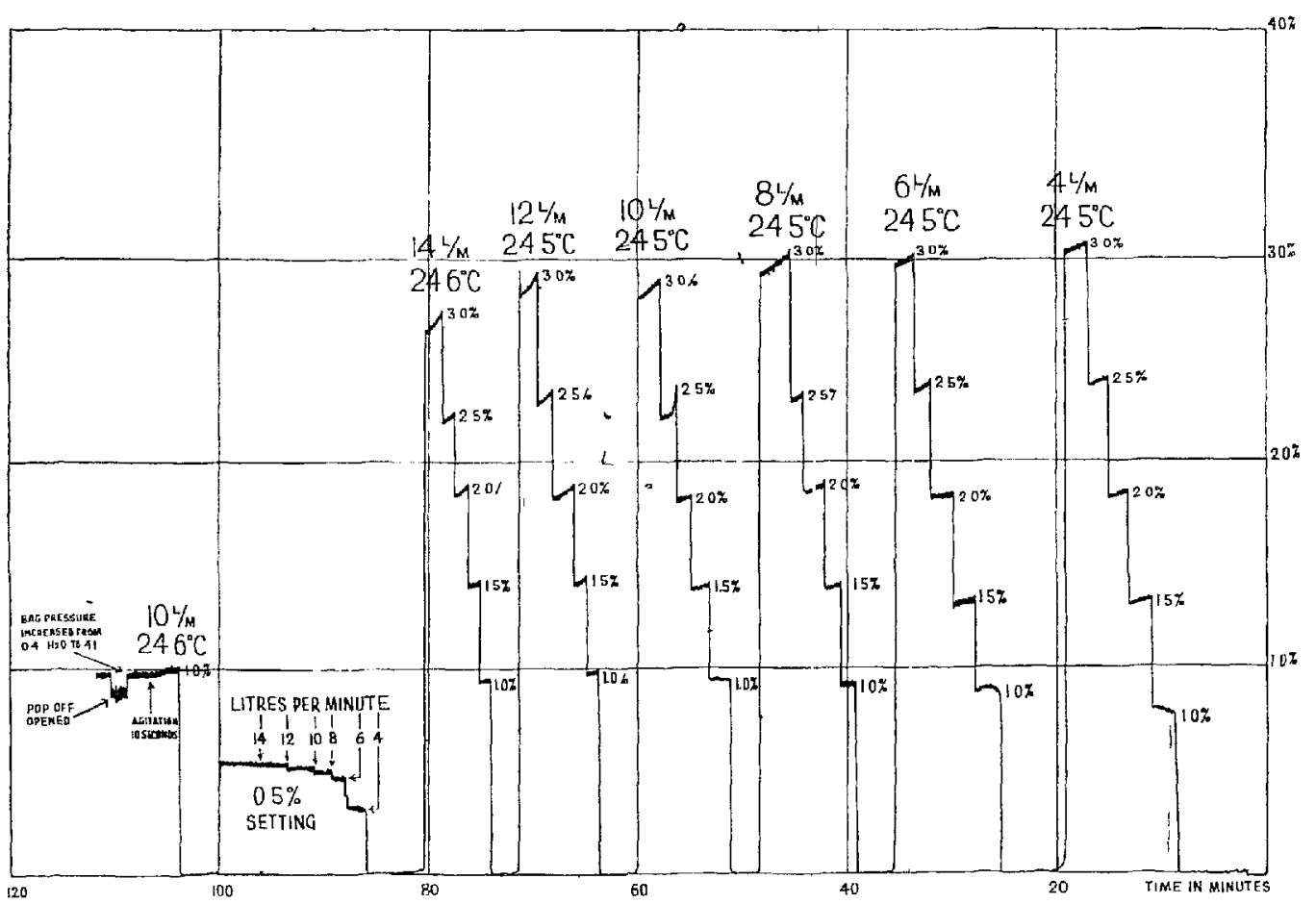

FLUOTEC VAPORIZER

FIGURES NOTED BESIDE PEAKS INDICATE VAPORIZER DIAL SETTING ACTUAL OBSERVED PERCENTAGES ARE INDICATED ON THE RIGHT ORDINATE Frgure 6

Figure 7 shows the recording for the Ohio Fluothane Vaporizer. It will be noted that at the 0.5 per cent settung the actual delivery of Fluothane is about 0.6 per cent and that all other settings deliver much less than the predicted concentration at $4 \mathrm{~L} . / \mathrm{min}$. How At $8 \mathrm{~L} . / \mathrm{min}$ flow there is little change in the lower range but settmgs of 25 per cent and 3 per cent come much closer to accuracy

Figures 8 and 9 show the delivery of the FNS Vaporizer It will be observed that at all lower dial settings this vaporizer delivers much less Fluothane than the setting would indicate At $6 \mathrm{~L} . / \mathrm{min}$. flow and at $8 \mathrm{~L} / \mathrm{min}$ flow with the level of the Fluothane close to the upper mark on the bottle, at the 28 per cent setting, the 24 per cent setting and the 2 per cent setting the vaporizer comes within 20 per cent accuracy Low range settings, however, will be noted to be consistently inaccurate Two dufferent FNS Vapornzers were studied and it was observed that there was some difference between them, perhaps due to mass calibration of these instruments

Figure 10 shows the delivery of the BOC Fluothane Vaporizer at flow rates of $4 \mathrm{~L} . / \mathrm{min}, 6 \mathrm{~L} / \mathrm{mm}$, and $8 \mathrm{~L} / \mathrm{mm}$. It will be abserved that the dial settings are not percentage settings, and that the scale settings do not give a linear curve It may be seen however, from this record that an intial setting of 6 or 7 might be necessary to obtain a concentration of 3 per cent Fluothane and that a setting of 2 would usually be adequate for maintenance. Settings higher than 7 on this vaporizer delivered a concentration of more than 6 per cent Fluothane, and would not record on the spectrophotometer without changing the range. 


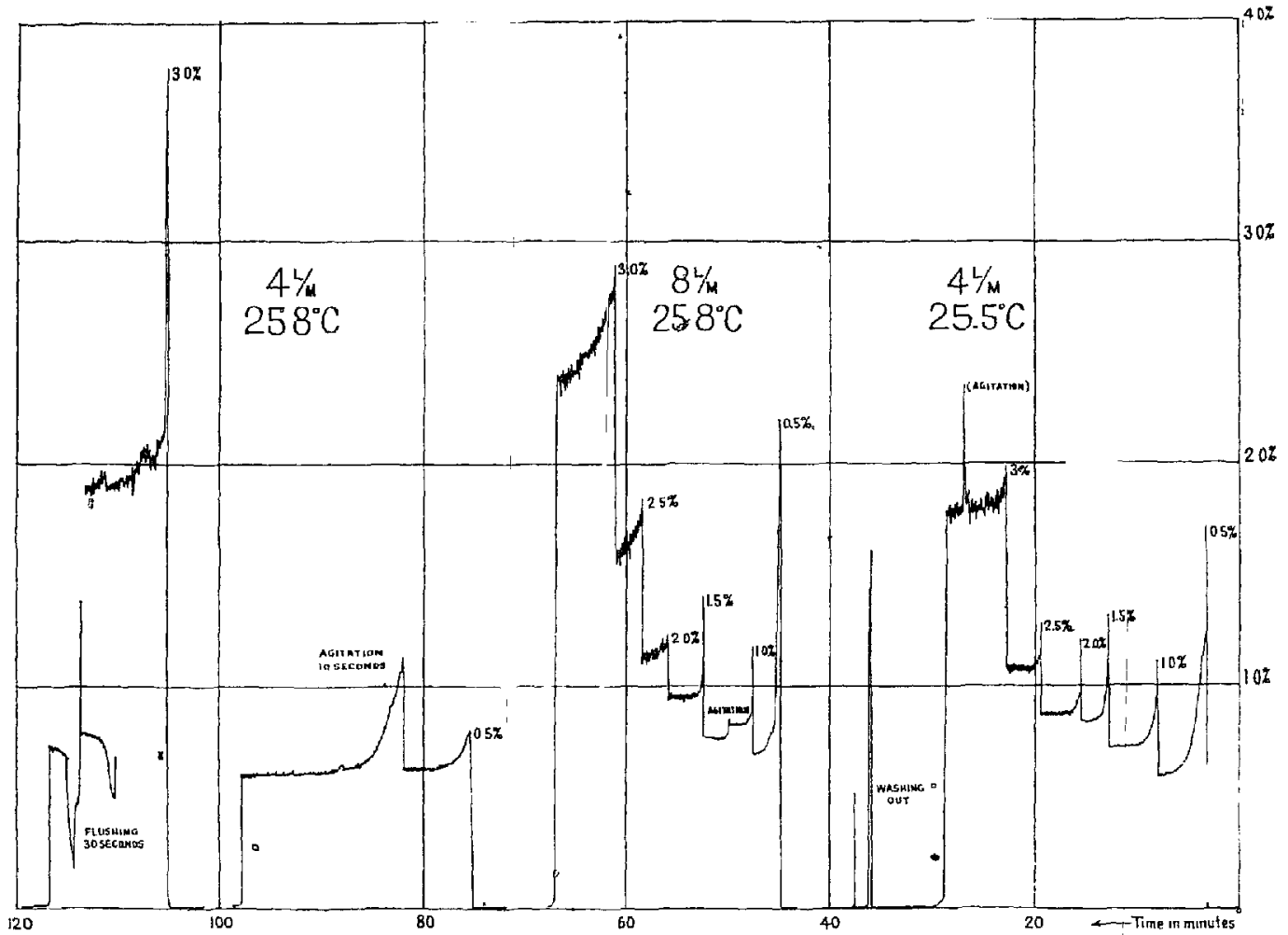

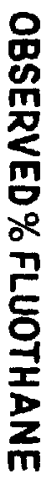

\section{OHIO FLUOTHANE VAPORIZER}

FIGURES NOTED BESIDE PEAKS INDICATE YAPORIZER DIAL SET TING

ACTUAL OBSERVED PERCENTAGES ARE INDIGATED ON THE RIGHT ORDINATE

FIGURE 7

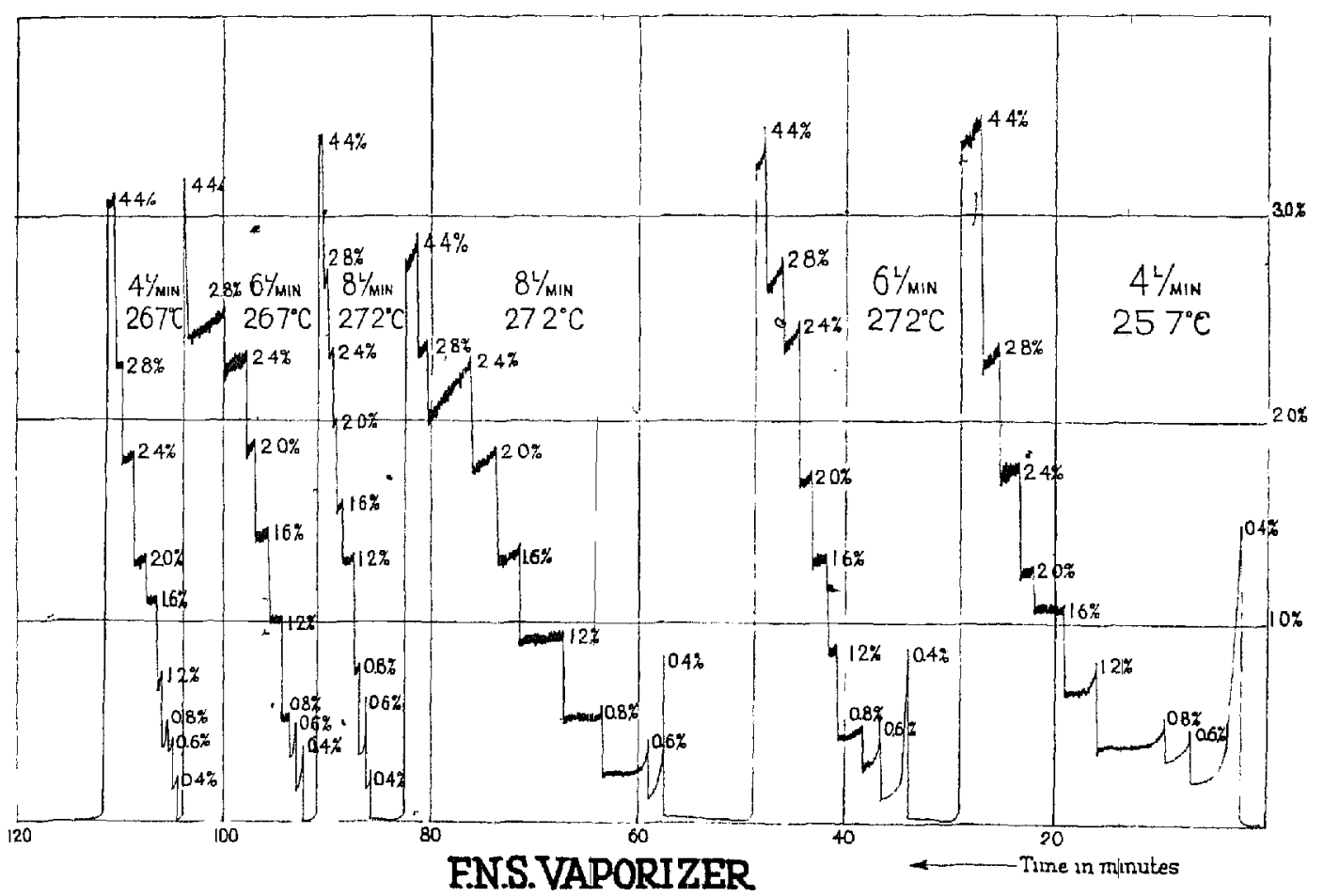

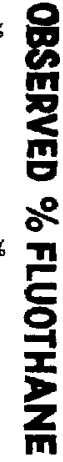

FIGURES NOTED BESIDR PEAKS ITDICATE VAPORIZER DIAL SETTING AGTUAL OESERVED PERCENTAOES ARE INDJCATED ON THERIOHT ORDINATE 


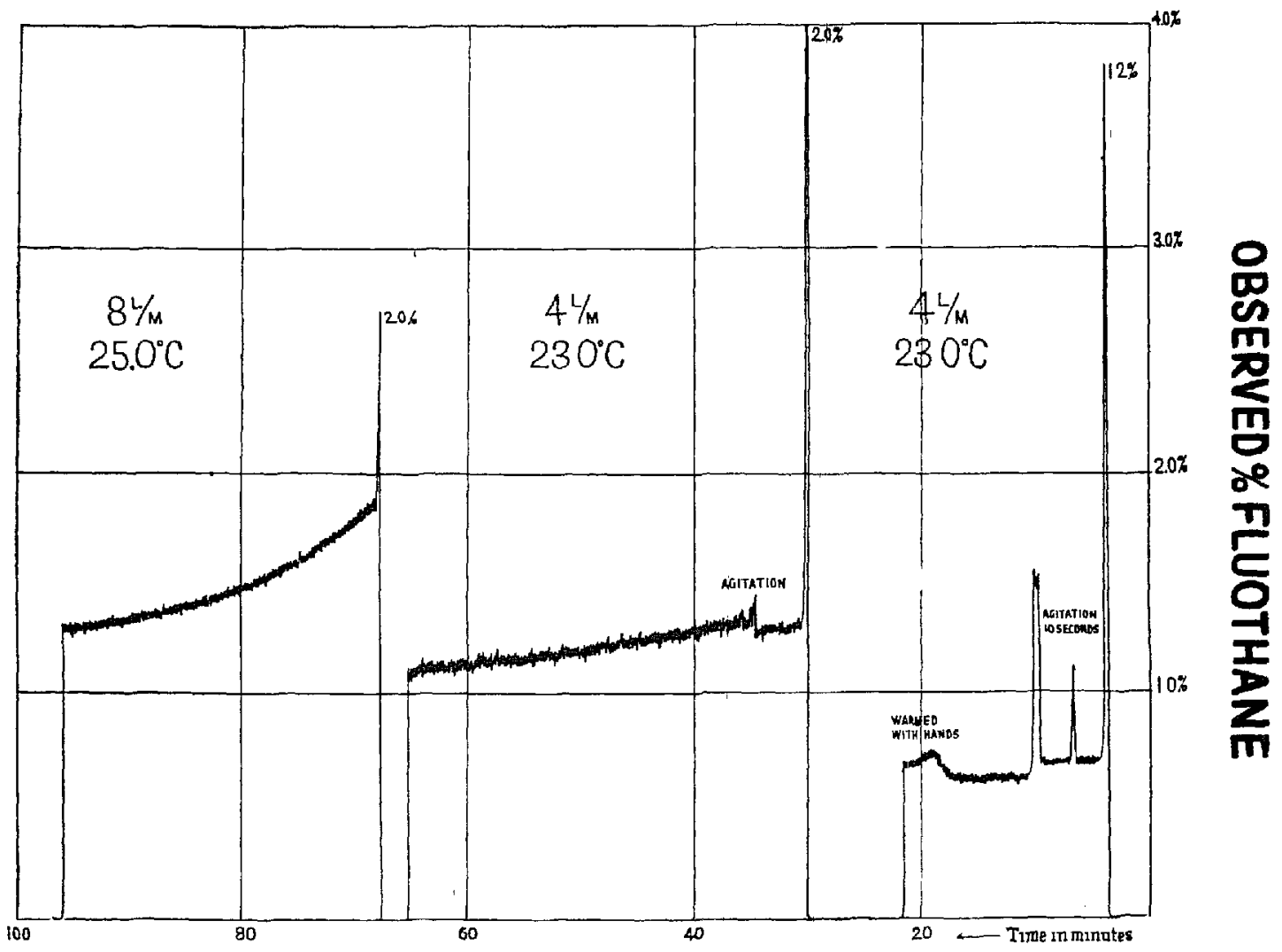

F.N.S. VAPORIZER

FIGURES NOTED BESIDE PEAKS INDICATE WAPORIYER DLI SETTNG ACTUAL OBSERVED PERICEN TAGES ARE INDICATED ON THF RIGHT ORDINATE

Figure 9

It will be noted on all of these records that the vaponzers tend to deliver in their lower range somewhat higher concentrations of Fluothane with increase in gas flow

All of the vaporizers with the exception of the Fluotec deliver at any mitial scale setting an excessive concentration of Fluothane for the first one to three minutes before settilng to a reasonably constant level (Figs. 7, 8, 9, and 10). The FNS Vaporizer and the Ohio Vaporizer also demonstrate this phenomenon on changing from any setting to a higher one.

With the exception of the Fluotec all vaponzers react very sensitively to agitation by delivering for a period up to five minutes duration a higher concentration of Fluothane (Figs. 7, 9, and 10). Figure 6 shows that agitation of the Fluotec Vaporizer produces no effect.

Increasing the pressure within the system from $1 \mathrm{~cm}$ of water to $10 \mathrm{~cm}$ of water caused a very slight fall in the delivered concentration of Fluothane with the Fluotec Vaporizer (Fig 6). This effect was much less with the other vaporizers.

The falling off in delivered concentration of Fluothane at low scale settings due to the cooling effect is least noticeable with the Fluotec and is not serious 


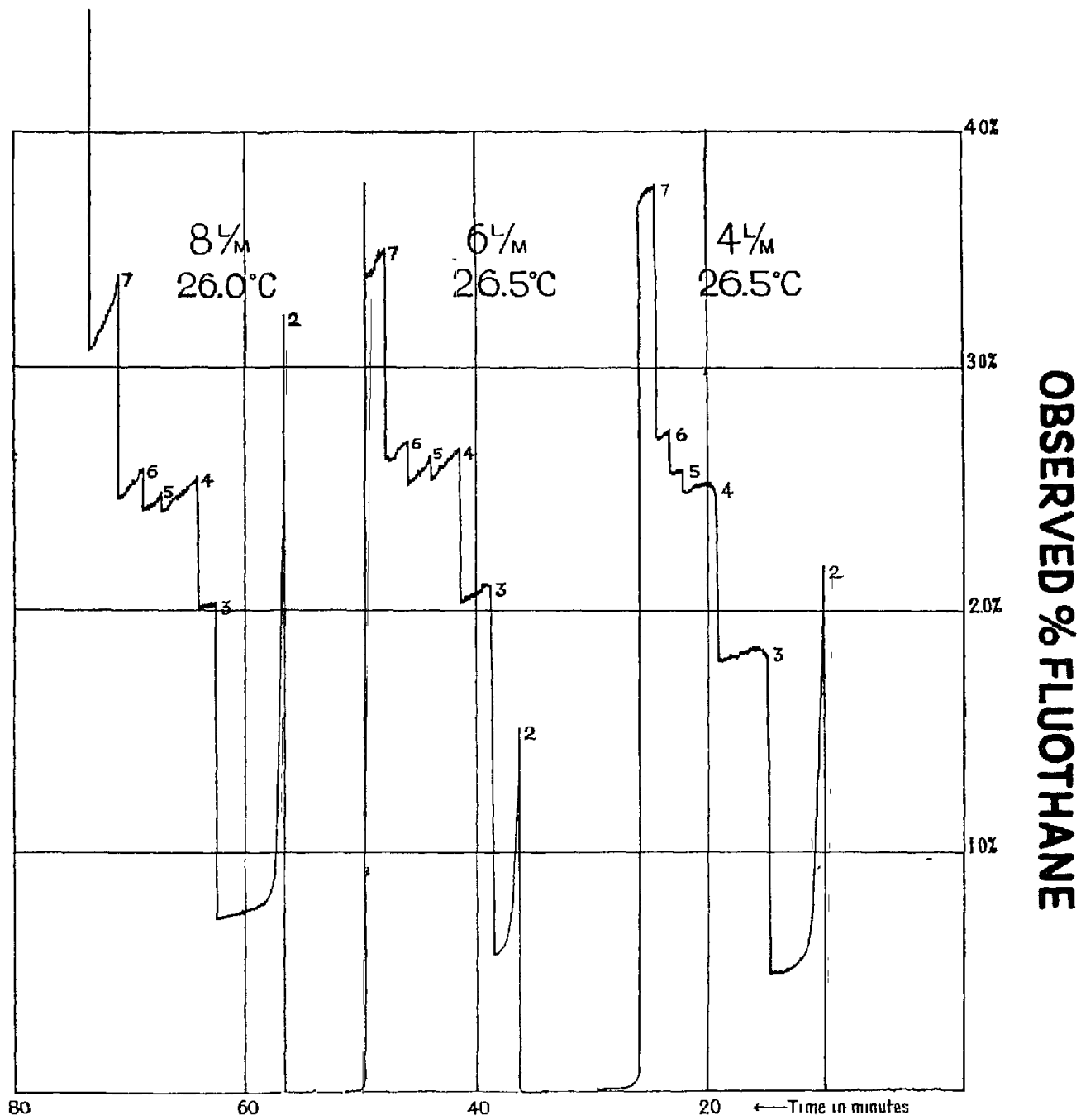

\section{B.O.C. FLUOTHANE VAPORIZER}

FIGURES NOTED BESIDE PEAKS INDICATE VAPORIZER DIAL SETTING ACTUAL OBSERVED PERCENTAGES ARE INDICATED ON THE RIGHT ORDINATE

Figure 10

for some tıme with any of the other vaponzers At high diąl settungs fall off $\mathrm{m}$ concentration due, to cooling is most noticeable with the BOC Vaporizer and the FNS Vaporizer, but occurs to some extent in both of the others as well

Flushing the vaporizers through with oxygen at high flow causes some drop in concentration delivered with each of the vaporizers This was of little effect at mantenance settungs although at high settungs it produced vanable effects

In Figure 7 a peak will be observed with the legend beside it "Washing out" This phenomenon was observed if the gas flow had been completely turned off and then restarted and is an indication of the high solubility of Fluothane in rubber. This may account for a very small part of the difference between observed and predicted concentrations. 


\section{Discussion and Conclusions}

The clinical and laboratory investigation of four Fluothane vaporizers has shown a marked variation in their efficiency. It would appear that the Ohio Vaporizer and the FNS Vaporizer have been calibrated by a method necessitating the collection of a gas sample over a period of at least thrrty seconds and probably more. This is shown by the discrepancy between the observed percentage and the true delivered percentage of Fluothane after a stable level has been attained. The inital peak at any setting has probably been included in the sample obtained thus giving a false percentage estimation. Agitation of all of the vaporizers with the exception of the Fluotec can deliver dangerously high concentrations of Fluothane. Although this may persist for less than one or two minutes it may be of considerable importance when dealing with patients who are not robust, or with children. It is concluded that whlle all four vaporizers are useful the Fluotec is the most accurate, most efficient and the safest, particularly for long surgical procedures. One can, however, become used to any of the other vaponzers with little trouble. The fact should be stressed that no matter what vaporizer, what drug, or what gas machıne is being used for any procedure, careful observation of the patient's condition is still of the utmost importance and that no piece of apparatus can substitute for clinical experience and judgment.

\section{ACKNOWLEDGMENTS}

The authors wish to thank Canam Surgical Services, Ltd, Ohıo Chemical Canada, Ltd, the British Oxygen Ltd Canada, for their co-operation in making this clinical and laboratory investigation possible, and Mr. Walter Rayson for preparing figures $6,7,8,9$ and 10 .

\section{RÉSUMÉ}

A la surte de l'intérêt qu'on a porté, récemment, au Fluothane, on a dû fabriquer plusieurs vaporisateurs pour administrer cet agent anesthésique puissant. Cet article fait part des résultats des recherches de laboratoire et des recherches cliniques faites avec quatre vaporisateurs de Fluothane. le Fluotec, le Heidbrink, le F.N.S. et le B.O.C. Les trois premiers sont calıbrés et le dernier possède une échelle arbitraire étendue.

En clinique, les quatre vaporisateurs ont leur utilité. Incontestablement, le plus précis c'est le Fluotec; il est excellent pour maintenir une anesthésie à n'importe quel plan car la concentration désignée demeure la même pendant très longtemps. Quant aux trois autres, il faụt les remplir souvent car les modifications des niveaux de liquide entraînent des changements dans la concentration des vapeurs. Parmi les trois derniers, le Heidbriak doıt être rempli moins souvent et donne des variations moindres que les vaporisateurs F.N.S. et B.O.C.

Le vaporisateur Fluotec permet d'administrer au malade la plus faible concentration possible de Fluothane qu'on puisse utiliser pour le maintien d'une anesthésie et permettre au malade de se réveiller immédiatement après l'opération. Le vaporisateur Heidbrink nous semble être presqu'aussi efficace, à ce point 
de vue, au débit pour lequel $\mathrm{l}$ est calibré. Avec le vaporisateur F.N.S., on a observé une différerice prononcée, sur toute l'échelle, entre les quantités débitées et la calibration et, de ce fait, il faut, pour le maintien de l'anesthésie, le placer à une calibration beaucoup plus haute

Dans le laboratorre, à des débits de 6 à 12 .litres par minute, les Fluotecs se sont avérés d'une précision à $0.1 \%$. A un débit de 4 litres par minute, la concentration en Fluothane est quelque peu inférieure à ce qu'indique la calibration, mais on peut dire jusquà quel point elle diffère et elle demeure stable. Dans les limites du maintien de l'anesthésie (0.5 à $1.0 \%)$, le vaporisateur Heidbrink offre une précision raisonnable à un débit de 4 litres par minute pour lequel il est calibré ainsi qu’à 8 litres par minute. Dans la partie supérieure de son échelle, Il ne donne pas la concentratıon qu'il indique sur la calibratıon. A des débits de 4 et 8 litres par minute, les vaporisateurs F N S. donnent une concentration en Fluothane beaucoup mgindre que ne l'indique la callbration A part cela, il exıste des différences considérables entre les vaporısateurs F.N.S. Le vaporısateur B.OC, à la dose d'entretien sur son indicateur de 2-2.5, donne des concentrations de Fluothane de tout repos, mais, au bout de son indicateur, ll peut donner att-delà de 6\%. A forts débits, les vaporisateurs Heidbrink, F N S et $\mathrm{B} \mathrm{OC}$. ont tendance à donner des concentrations de Fluothane supérieures à ce qu'indique la calibration.

Tous les vaporisateurs, à l'exception du Fluotec, donnent au début, à toutes les faibles calibrations, une concentration excessive de Fluothane au cours des deux premières minutes puis, par la suite, se stablisent à des concentrations constantes. Les vaporisateurs F.N.S. et Heidbrink se comportent de la même façon quand on passe d'une calibration donnée à une calibration supérieure $\mathrm{Si}$ on les agite, tous les vaporisateurs, à l'exception du Fluotec, donnent une concentration plus élevée en Fluothane.

Dans les petites calibrations, la diminution de la concentration en Fluothane, quand on abaisse la température ambiante ou qu'on diminue le débit de gaz, est moins importante avec les vaporisateurs Fluotec et Heidbrink et plus considérable avec le B.O C. Dans les grandes calıbrations, on observe une diminution de concentration en Fluothane pour tous les vaporisateurs dans les mêmes circonstances, mais elle est moins marquée avec le Fluotec à n'importe quel débit.

Avec le Fluotec, la concentration en Fluothane devient moindre si l'on au $3-$ mente légèrement la pression dans le circuit. Avec les autres vaporisateurs, a concentration est peu changée.

En guise de conclusion, on peut affirmer que, si les quatre vaporisateurs peuvent être utiles, le Fluotec, toutefois, deneure le plus précis et le plus efficace, qu'une calibration globale n'est pas assez précise pour un agent aussi puissant, qu'aucun vaporssateur, ni aucune machine, quelle qu'en soit la précision, ne pourra remplacer l'observation attentive du malade.

\section{REFERENCES}

1. Kalow, W. Spectrophotometric Determination of Flnothane Vapour. Canad. Anaesth. Soc. J. 4. 384 (October, 1957). 